\title{
New Dimension in Fish Immunotherapeutics: Avian Egg Yolk Antibody (IgY)
}

\author{
Tapas Paul ${ }^{1}$, Anirban Pal $^{2}$, Sampa Pal ${ }^{3}$ and Nilav Aich ${ }^{3 *}$ \\ ${ }^{1}$ Division of Aquatic Environment and Health Management, ICAR-CIFE, Mumbai, India \\ ${ }^{2}$ ICAR-Central Institute of Freshwater Aquaculture, Odisha, India \\ ${ }^{3}$ Department of Fisheries, Tripura, India
}

*Corresponding author

\begin{tabular}{l} 
K e y w o r d s \\
Chicken \\
Immunoglobulin \\
(IgY), Aquaculture, \\
Infectious disease \\
\hline Article Info \\
\hline $\begin{array}{l}\text { Accepted: } \\
\text { 04 June } 2019 \\
\text { Available Online: } \\
\text { 10 July } 2019\end{array}$ \\
\hline
\end{tabular}

A B S T R A C T

Intensification in aquaculture practices has resulted the development of various diseases caused due to pathogens and water quality issues. In recent times, the usage of antibiotics for controlling bacterial diseases in aquaculture has been proven unsustainable and barren due to development of antibiotic resistance in pathogens one of the greatest human health challenges of the 21 st century. Many measures have been used as potential alternatives to antibiotics including organic and inorganic acids, antibodies, probiotics and herbal products. Oral administration of Immunoglobulin (IgY) has attracted significant attention worldwide as a means of controlling infectious diseases of bacterial and viral origin in fishes due to its high specificity. In the present review, a holistic approach was studied to summarize the mode of action of $\operatorname{IgY}$, advantage and application of $\operatorname{IgY}$ in aquatic organisms.

\section{Introduction}

Antibodies are called immunoglobulins, a set of glycoprotein secreted by plasma cells in response to antigen exposure. Since last few decades antibodies are being used widely in the field of disease diagnosis, quantification and identification of specific antigens (Amro et al., 2018). Till recent year animal species were primary choice for researchers to produce specific antibody which involves steps like immunizing the animal with specific antigen, collection of blood, purification of antigen. Such process most of the times leads to death of the animal due to excessive loss of blood. With the discovery of $\operatorname{IgY}$ in the bird egg it has started to gain importance and broader application due to several advantages over mammalian antibodies produced. Chicken serum IgY transported to egg following similar pattern of placental transfer of IgG in mammals to protect the newly hatched chicken by providing passive immunity. Following similar function like 
$\mathrm{IgG}$, molecular structure of $\operatorname{IgY}$ is different from $\mathrm{IgG}$, but shows similarity with mammalian IgE and IgA (Warr et al., 1995, Ambrosius, 1996). Thus, it is postulated that IgY is phylogenetic progenitor of mammalian IgE and IgA (Carlender, 2002). In this review we will discuss about the multidimensional application of $\operatorname{IgY}$ in the field of aquaculture and fish health management.

\section{Structure and Properties}

IgY contain two heavy chain and two light chain resembles a $\mathrm{Y}$ like structure. Unlike mammalian IgG, this antibody has higher molecular weight due to presence of extra constant (CV2) domain in heavy chain (Warr et al., 1995). CV3 and CV4 constant region of heavy chain of $\operatorname{IgY}$ shows some similarity with CV2 and CV3 of IgG (Shizimu et al., 1992). However, the hinge region of IgY is not well developed. The undeveloped hinge region alters the flexibility of Fab region which may cause some difference in the epitope recognition for $\operatorname{IgY}$ and $\operatorname{IgG}$ (Cser et al., 1982 and Noll et al., 1982). To consider a candidate for oral administration stability to lower $\mathrm{pH}$ is one of the important properties of an antibody. $\operatorname{Ig} Y$ unlike $\operatorname{IgG}$ has lower stability in low $\mathrm{pH}$ (Calzado et al., 2005). $\operatorname{IgY}$ rapidly lost its activity near $\mathrm{pH}-4.0$ to $\mathrm{pH}-3.0$ (Lee et al., 2002; Hatta et al., 1993). To suppress the inactivation of $\operatorname{IgY}$ at lower $\mathrm{pH}$ scientists have developed various techniques so that it can be prevented. Addition of 50\% sorbitol with $\operatorname{IgY}$ found to have prevented low $\mathrm{pH}$ inactivation (Lee et al., 2002). Increases use of alkaline (Sodium Bicarbonate) and egg white found effective to provide resistance against acid inactivation and proteolytic cleavage. IgY shows more resistance against trypsin and chymotrypsin (Calzado et al., 2005). $\operatorname{IgY}$ is stable at higher temperature like $60-70^{\circ} \mathrm{C}$. Some scientist has also found $100 \%$ stable $\operatorname{IgY}$ even at 100 degree centigrade (Lösch et al., 1986).

\section{Transport to egg}

Concentration of $\operatorname{IgY}$ is much higher (5 to 15 $\mathrm{mg} / \mathrm{ml}$ ) than $\operatorname{IgM}$ (1 to $3 \mathrm{mg} / \mathrm{ml}$ ) in blood serum (Rose et al., 1974; Kowalczyk et al., 1985). It took 5-6 days for the $\operatorname{IgY}$ to appear in the egg yolk after detection in serum (Davison et al., 2008). Amount of $\operatorname{IgY}$ in egg is positively correlated with amount in serum. However, concentration of $\operatorname{IgY}$ differ with species and within chicken lines (Carlander, 2002). The Fc and hinge region play important role in transfer of $\operatorname{IgY}$ from serum to egg (Mohammed et al., 1998; Morrison et al., 2001). Though there are some contradictions in studies shows presence of IgM and IgA in egg yolk but recent studies show that IgY is exclusively transported to egg via a receptor mediated endocytosis (Kitaguchi et al., 2008). Studies found that all immunoglobulins transported to yolk have a characteristic HEAL (His-Glu-Ala-Leu) sequence (Calzado et al., 2005). Some birds and reptiles contain truncated form of $\operatorname{IgY}$ which is devoid of terminal domain in heavy chain. Such truncated $\mathrm{IgY}$ transported to egg via fluid based endocytosis (Kitaguchi et al., 2008). Schade et al., (1994) found that around 100$200 \mathrm{mg}$ of $\operatorname{IgY}$ found in egg with $2-10 \%$ antigen specific $\operatorname{IgY}$.

\section{Advantages of using IgY}

One of the major advantages of using $\operatorname{IgY}$ over other antibodies is their non-invasive way of production and purification. The production of IgY involves a non-invasive method that includes immunizing host with specific antigen. The antibody will be produced in the chicken mother will eventually transferred into egg. A chicken produces 260-300 eggs per year. From each egg 100-200 mg of antibody can be produced with 2-10\% of with Ag specific antibody (Schade et al., 1994; Carlander, 2002). Thus 20-40 $\mathrm{mg}$ of $\mathrm{IgY}$ can be produced from single bird without causing 
any damage. A large proportion of antibody lost in the guts when administered orally. This is largely due to enzymatic inactivation of antibody and lower $\mathrm{pH}$ of guts. Thus, a high quantity of $\mathrm{Ab}$ required for oral administration. Higher yield of IgY antibody in cheaper cost make it possible for the treatment of animals orally.

Specially in case of fishes, where individual injection becomes tedious job, oral treatment provides greater advantage because target species can be administered specific $\operatorname{IgY}$ mixing with feed.

Stability at higher temperature is necessary for making antibodies in powder form. IgY is stable at higher temperature of $60-70^{\circ} \mathrm{C}$. Some scientist has also found $100 \%$ stability of IgY even at $100 \stackrel{\circ}{\circ}$. Birds are phylogenetically distant to fishes, which reduces any threat of cross reactivity of IgY with fish epitopes, Fc segment etc. Besides that, birds need small amount of antigen to produce large quantity of IgY which shows remarkably high affinity, high avidity and highly neutralizing ability against infectious pathogen (Zorriehzahra et al., 2016).

\section{Mode of Action}

Mode of action of $\operatorname{IgY}$ is yet to determine. However, four principal mode of action of IgY have been proposed by the scientists includes agglutination, adherence blokade, opsonization followed by phagocytosis and neutralization of pathogen.

\section{Agglutination}

Agglutination of virus, parasites and bacteria causes immobilization, thereby prevent their growth. Tsubokura et al., (1997) observed prevention of growth of bacteria and reduced the CFU count due to agglutination following the treatment of $\operatorname{IgY}$.

\section{Adherence Blokade}

Inhibition of adherence in the cell surface seems to be the principal mechanism of $\operatorname{IgY}$ in preventing bacterial infection (Lee et al., 2002; Jin et al., 1998). IgY binds with the cell elements of bacteria such as pili or fimbriae, lipopolysaccharides and other membrane bound proteins that are responsible for adherence for the bacteria into host tissue (Xu et al., 2011). Such binding not only reduce the adherence but also stop the cell signaling process responsible for release of toxins and other growth enhancing protein (Xu et al., 2011).

\section{Phagocytosis followed by opsonization}

IgY reported to have increase the phagocytosis against pathogen. Improved phagocytosis of Staphylococcus aureus by neutrophils were observed after treatment with IgY (Nie et al., 2004). Presence of IgY increase phagocytosis activity of E. coli by milk macrophages and polymorphonuclear neutrophil leukocytes (Zhen et al., 2008). Binding of $\operatorname{IgY}$ in the surface of Salmonella typhimurium and E. Coli O111 make them susceptible to phagocytosis (Lee et al., 2002).

\section{Neutralization}

IgY prevent internalization of $\mathrm{S}$. aureus by mammalian epithelial cell leads to neutralization of toxin. Wang et al., (2011) suggested possible treatment of mastitis may only be possible by blocking of internalization of $\mathrm{S}$. aureus or by neutralizing the toxin rather than focusing on growth inhibition by IgY.

\section{Application of IgY in Fisheries and Aquaculture}

\section{Application in disease control}

One of the major threats for the growth of aquaculture industry is outbreak of diseases. 
Intensification of the culture systems makes the sector more vulnerable to diseases. Resistance to most of the antibiotics drives the scientific community to find an alternative solution to control and manage diseases. Passive immunity is a method to transfer specific antibody against a bacteria into the healthy fishes even before the occurrence of disease is an ideal technique for treatment of fish and other aquatic animals.

Treatment with antibody is getting importance in the aquaculture especially due to its nonharmful nature and also there is no threat of bacteria developing resistance. IgY due to is high production potential and easy extraction methods make itself the ideal antibody to carry out such treatment. Several scientists have tried to use $\operatorname{IgY}$ for both, providing passive immunity to fishes and also therapeutics treatment and found surprising results. Applications of $\operatorname{IgY}$ in fisheries are summarized in Table 1.

WSSV in shrimp causes severe economic loss over the years. Passive immunization of shrimp against WSSV by producing antiviral antibody against VP28 and VP19 protein neutralize viral particle ( $\mathrm{Lu}$ et al., 2009). Two different methods have been tried to produce antiviral IgY. Chicken Injected with inactivated WSSV and also by introducing DNA vaccine encoding specific gene. However, the result shows higher affinity by IgY for WSSV when obtained through inactivated WSSV than IgY obtain through DNA vaccine. Effectiveness of treatment studied in Crayfish (Procambarus clarkii) and it was found that intramuscular injection, oral and immersion all were effective (Lu et al., 2009; Xu et al., 2011). Yersinia ruckeri causes enteric red mouth disease in Rainbow trout. These microbes get released by carrier fish with faeces and persist for longer period. Oral administration of anti $Y$. ruckeri antibody followed by immersion in water containing bacteria results in lower mortality (Lee et al., 2000). Oral treatment also leads to lower count of this bacteria into guts. Aeromonas salmonicida causes serious ulcer in Koi carp, erosion of skin and subsequent exposure of muscle. A. salmonicida specific IgY antibody produced and purified. Purified antibody injected into Koi carp, immunised fishes with anti A. salmonicida antibody is then immersed in water containing A. salmonicida. Immunised fishes show significant protection (Gan et al., 2015). Li et al., (2006) inhibited the growth of Aeromonas hydrophila in Carassius auratus gibelio using anti $A$. hydrophila antibody. Formalin killed bacteria used to immunise hen. ELISA test confirms peak antibody production after 56 days. $60 \%$ fishes show survivability after challenged with Aeromonas hydrophila. It was also observed complete inactivation of bacteria at $1 \mathrm{mg} / \mathrm{ml}$ concentration of specific $\mathrm{Ab}$ in bacterial culture. Another study of Vibrio anguillarum in Japanese Ayu (Plecoglossus altivelis) shows a survivability of $64 \%$ and $55 \%$ incase of passive immunization and therapeutics treatment by specific $\mathrm{IgY} \mathrm{Ab}$ respectively $(\mathrm{Li}$ et al., 2014). Besides that Oral administration of specific antibody could leads to increase in the phagocytosis activity of macrophages, decreases expression of groups of cytokines includes TGF- $\boldsymbol{\beta}, \mathrm{TNF}-\boldsymbol{\alpha}$ and IL- $\boldsymbol{\beta}$ (Li et al., 2014; Zorriehzahra et al., 2016). Another treatment of Vibrio anguillarum in half smooth tongue sole (C. semilaevis) with encapsulated specific anti-IgY shows $70 \%$ survivability when challenged with bacteria (Gao et al., 2016). Encapsulation were done to prevent enzymatic inactivation of antibody in intestinal gut. Edwardsiella tarda causes infection through intestinal mucosa in Japanese eel. Oral treatment with specific IgY shows good survivability with no disease syndromes. Similarly, abalone when treated with encapsulated specific IgY shows $65-70 \%$ survivability (Hatta et al., 1993; Hatta et al., 1994). 
Table.1 Application of IgY in fisheries and aquaculture

\begin{tabular}{|c|c|c|c|c|}
\hline \multicolumn{5}{|c|}{ Application in Disease Control } \\
\hline Disease & Pathogen & Target species & Effects of IgY & Reference \\
\hline $\begin{array}{l}\text { White spot } \\
\text { syndrome }\end{array}$ & $\begin{array}{l}\text { White spot syndrome } \\
\text { virus }\end{array}$ & $\begin{array}{c}\text { Shrimp (P. } \\
\text { monodon) } \\
\\
\text { Crayfish } \\
\text { (Procambarus } \\
\text { clarkii) }\end{array}$ & $\begin{array}{l}\text { Passive immunization of } \\
\text { shrimp against WSSV } \\
\text { infection } \\
\text { Provide protection to } \\
\text { Crayfish from WSSV }\end{array}$ & $\begin{array}{l}\text { Xu et al., } \\
2011\end{array}$ \\
\hline Vibriosis & V. alginolyticus & $\begin{array}{c}\text { Abalone } \\
\text { (Haliotis Sp.) }\end{array}$ & $\begin{array}{l}\text { Increase resistance against } \\
\text { vibriosis, Reduced } \\
\text { mortality rate }\end{array}$ & $\begin{array}{l}\text { Lee } \text { et al., } \\
\quad 2000\end{array}$ \\
\hline Furunculosis & A. salmonicida & Koi carp & $\begin{array}{c}\text { Immunized fishes show } \\
\text { significant protection } \\
\text { against } A \text {. } \\
\text { salmonicidainfection }\end{array}$ & $\begin{array}{l}\text { Gan et al., } \\
\quad 2015\end{array}$ \\
\hline $\begin{array}{c}\text { Enteric red } \\
\text { mouth disease }\end{array}$ & Yersinia ruckeri & Rainbow trout & $\begin{array}{l}\text { Oral administration of IgY } \\
\text { results in reduced mortality } \\
\text { rate }\end{array}$ & $\begin{array}{l}\text { Lee } \text { et al., } \\
\quad 2000\end{array}$ \\
\hline Aerominasis & A. hydrophila & $\begin{array}{l}\text { Carassius auratus } \\
\text { gibelio }\end{array}$ & $\begin{array}{c}\text { Increased solvability by } \\
60 \%\end{array}$ & Li et al., 2006 \\
\hline Edwardsiellosis & E. tarda & Abalone & $\begin{array}{l}\text { Oral treatment shows good } \\
\text { survivability, Prevented } \\
\text { paracolo disease } \\
\text { Encapsulated specific IgY } \\
\text { shows } 65-70 \% \\
\text { survivability }\end{array}$ & $\begin{array}{l}\text { Hatta et al., } \\
\qquad 1993 \\
\text { Hatta et al., } \\
\quad 1994\end{array}$ \\
\hline Vibriosis & Vibrio anguillarum & $\begin{array}{l}\text { Half smooth } \\
\text { tongue sole }(C \text {. } \\
\text { semilaevis })\end{array}$ & $\begin{array}{l}\text { Encapsulated specific anti- } \\
\text { IgY shows } 70 \% \\
\text { survivability when } \\
\text { challenged with bacteria. }\end{array}$ & $\begin{array}{l}\text { Gao et al., } \\
2016\end{array}$ \\
\hline \multicolumn{5}{|c|}{ Application in Detection and Control of food borne disease } \\
\hline $\begin{array}{l}\text { Food borne } \\
\text { illness/Toxin }\end{array}$ & Causative Agent & $\begin{array}{c}\text { Method to } \\
\text { detect/Control }\end{array}$ & Effect of IgY & Reference \\
\hline Ciguatoxin & Gambierdiscus toxicus & Sandwich ELISA & $\begin{array}{l}\text { Reliable results in } \\
\text { detection }\end{array}$ & $\begin{array}{l}\text { Campora et } \\
\text { al., } 2008\end{array}$ \\
\hline $\begin{array}{l}\text { Specific } \\
\text { Spoilage } \\
\text { Bacteria }\end{array}$ & $\begin{array}{c}\text { Shewanella putrefaciens, } \\
\text { Pseudomonas } \\
\text { fluorescens }\end{array}$ & $\begin{array}{l}\text { Addition of IgY as } \\
\text { preservative }\end{array}$ & $\begin{array}{l}\text { Increase shelf life of fish } \\
\text { product in cold storage }\end{array}$ & $\begin{array}{l}\text { Xu et al., } \\
2012\end{array}$ \\
\hline Meningitis & Listeria monocytogenes & $\begin{array}{l}\text { Addition of } \operatorname{IgY} \text { as } \\
\text { preservative }\end{array}$ & $\begin{array}{l}\text { Inhibits growth in smoked } \\
\text { and fresh salmon flesh }\end{array}$ & $\begin{array}{l}\text { Sui et al., } \\
\quad 2011\end{array}$ \\
\hline
\end{tabular}




\section{Application in detection and prevention of seafood contamination}

A major sea food borne illness caused by Ciguatoxin in human after consumption of reef-based fishes. This toxin is released by Gambierdiscus toxicus, a dinoflagellate accumulates in the skin, head, muscle and viscera of fishes which cannot be destroyed by cooking at higher temperature. IgY based sandwich ELISA developed to detect Ciguatoxin gives very reliable result (Campora et al., 2008). Thus, IgY based immunodiagnostic techniques provide a cheap and more reliable platform in the field of detection of seafood contamination and immunodiagnostics kits can also be developed.

Specific spoilage organism (SSO) like Shewanella putrefaciens, Pseudomonas fluorescens responsible for spoilage of fishery product in aerobic cold storage. Use of SSO binding IgY antibody significantly prevent the microbial activity and thus significantly increase the shelf life of fishery product (Xu et al., 2012). Listeria monocytogenes, a bacterium responsible for food borne illness in human causes severe infection in the central nervous system. Contamination of seafood with L. monocytogenes has led to product recall. Therefore, bacteria possess serious threat to the seafood industry. Sui et al., (2011) inhibited the growth of bacteria in the smoked and fresh salmon flesh with specific antibody.

\section{Limitation}

One of the major limitations of $\operatorname{IgY}$ is acidic inactivation of $\operatorname{IgY}$ at lower $\mathrm{pH}$. When administered orally for passive immunotherapy, IgY reaches to the small intestine, which is the main target site. Upon reaching the small intestine IgY become very susceptible to proteolytic degradation and inactivation due to acidic environment. $\operatorname{IgY}$ is fairly resistant to proteolytic degradation (Hatta et al., 1993; Shimizu et al., 1988). But activity tends to decrease at $\mathrm{pH}-3.5$ and it completely lost its activity at $\mathrm{pH}-3.0$. Microencapsulation of antibody can be used as an effective method to prevent acidic inactivation and results showed a good portion of antibody is protected which resulted in better survival of fishes (Lee et al., 2000; Chang et al., 2002; Cho et al., 2005; Li et al., 2007; Wu et al., 2011). However, such measures will add additional amount of financial burden. Application of $\operatorname{IgY}$ as food preservative tend to decrease the microbial load for initial days but after few days the microbial concentration tend to increase which proves $\operatorname{Ig} Y$ is not fully effective food preservative. Further research is required in this area to use $\operatorname{IgY}$ a food preservative for longer time.

In the decade of increasing pressure of productivity, a sustainable remedial measure is the need of the hour. Many researchers have explored many alternatives but at present we can pompously say that IgY poses the great potential to stand high to solve all the issues in this scenario of crisis. The increasing resistance to antibiotics already leads to loss of crops and their residual effects also seem to impact the humans and other animals. Use of several chemicals also did not give encouraging results in addition to that it poses severe environmental coercions. In this scenario of high need for a long term, economical and effective control measure egg derived $\operatorname{IgY}$ will definitely boast the aquaculture production in coming future with its multidimensional advantages. The avian egg can accumulate a large quantity of antibodies which is highly effective as immunotherapeutic. It has been found that at a very short period of time high quality and quantity of antibodies can be obtained which is not possible by any other means. There are 
many encouraging results showing the effectiveness of $\mathrm{IgY}$ in fish against some devastating pathogens. There are many advantages of $\operatorname{IgY}$ which will attract the pharmaceutical companies to formulate monospecific or multifunctional antibodies. By using IgY we can reduce the cost of production many folds as its production cost is less and effectivity against pathogen is very high. There is no doubt about its effectiveness, at this point of time we need some more scientific evidence before it comes to the commercial market by overcoming some of its limitations. The future of fish and fisheries health management will be highly dependent on the success of avian egg derived IgY.

\section{Acknowledgement}

Authors of this manuscript acknowledge their respective institutes.

\section{References}

Ambrosius, H. 1996. Developmental aspects of immunoglobulins and antibodies. Altex 13, Suppl. 1, 10-14.

Campora, C E., Hokama, Y., Yabusaki, K., Isobe, M., 2008. Development of an enzyme-linked immunosorbent assay for the detection of ciguatoxin in fish tissue using chicken immunoglobulin Y. J Clin. Lab. Anal. 22: 239-245.

Carlander, D. 2002. Avian IgY Antibody. In Vitro and In Vivo. Acta Universitatis Upsaliensis, Comprehensive Summaries of Uppsala Dissertations from the Faculty of Medicine 1119, 153pp. Uppsala, Sweden: University of Uppsala.

Carlander, D. 2002. Avian IgY antibody: in vitro and in vivo. 53f. Phd Thesis University of Uppsala, Faculty of Medicine (Sweden).

Cser, L., Gladkih, I.A., Hädge, D. and
Ambrosius, H. 1982. X-ray small-angle scattering study of general structure of chicken immunoglobulin Y. Immunol Lett 4: 15-19.

Davison, F., Magor, K.E., Kaspers, B., Fred, D. and Karel, A.S., 2008. Structure and evolution of avian immunoglobulins. Avian Immunol, 1:107-127.

Gan, H., He, H., Sato, A., Hatta, H., Nakao, M. and Somamoto, T., 2015. Ulcer disease prophylaxis in koi carp by bath immersion with chicken egg yolk containing anti-Aeromonas salmonicida IgY.Res Vet Sci, 99:82-86.

Gao, X., Zhang, X., Sun, J., Du, X., Li, X., Zhang, Y. and Lin, L., 2016. Passive protection effect of anti-Vibrio anguillarum IgY-encapsulated feed on half-smooth tongue sole (Cynoglossus semilaevi) against $V$. anguillarum. Fish Shellfish Immunol., 56:483-488.

Hatta, H., Mabe, K., Kim, M., Yamamoto, T., Gutierrez, M.A., Miyazaki, T., 1994. Prevention of fish disease using egg yolk antibody. In: Sim JS, Nakai S (eds) Egg Uses and Processing Technologies, pp. 241-249. CAB International, Wallingford, UK.

Hatta, H., Tsuda, K., Akachi, S., Kim, M. and Yamamoto, T. 1993. Productivity and some properties of egg yolk antibody (IgY) against human rotavirus compared with rabbit IgG. Biosci., Biotechnol., Biochem. 57, 450-454.

Jin, L Z., Samuel, K., Baidoo, K., Marquardt, R.R., Frohlich, A.A., 1998. In vitro inhibition of adhesion of enterotoxigenic Escherichia coli K88 to piglet intestinal mucus by egg yolk antibodies. FEMS Immunol. Med. Microbiol 21:313-21.

Kowalczyk, K., Daiss, J., Halpern, J. and Roth, T.F., 1985. Quantitation of maternal-fetal IgG transport in the chicken. Immunology, 54(4), p.755.

Lee, E.N., Sunwoo, HH., Menninen, K., Sim, 
JS., 2002. In vitro studies of chicken egg yolk antibody (IgY) against Salmonella enteritidis and Salmonella typhimurium. Poult. Sci, 81: 632-41.

Lee, K.A., Chang, S.K., Lee, Y.J., Lee, J.H. and Koo, N.S. 2002. Acid stability of anti Helicobacter pylori $\mathrm{IgY}$ in aqueous polyol solution. J. Biochem. Mol. Bio. 35: 488-493.

Lee, S.B., Mine, Y. and Stevenson, R.M., 2000. Effects of hen egg yolk immunoglobulin in passive protection of rainbow trout against Yersinia ruckeri. J Agric Food. Chem, 48:110115.

Li, C.H., Lu, X.J., Li, D.F. and Chen, J., 2014. Passive protective effect of chicken egg yolk immunoglobulins against experimental Vibrio anguillarum infection in ayu (Plecoglossus altivelis). Fish Shellfish Immunol., 37:108-114.

Li, X.L., Shuai, J.B. and Fang, W.H., 2006. Protection of Carassius auratus Gibelio against infection by Aeromonas hydrophila using specific immunoglobulins from hen egg yolk. Journal of Zhejiang University SCIENCE B, 7:922-928.

Lösch, U., Schranner, I., Wanke, R. and Jürgens, L. 1986. The chicken egg, an antibody source. J. Vet. Med, 33:609619.

Lu, Y., Liu, J., Jin, L., Li, X., Zhen, Y., Xue, H., Lin, Q. and Xu, Y., 2009. Passive immunization of crayfish (Procambius clarkiaii) with chicken egg yolk immunoglobulin (IgY) against white spot syndrome virus (WSSV). Appl. Biochem. Biotechnol, 159:750.

Mohammed, S.M., Morrison, S., Wims, L., Trinh, K.R., Wildeman, A.G., Bonselaar, J. and Etches, R.J. 1998. Deposition of genetically engineered human antibodies into the egg yolk of hens. Immunotechnology 4:115-125.
Morrison, S.L., Mohammed, M.S., Wims, L.A., Trinh, R. and Etches, R., 2002. Sequences in antibody molecules important for receptor-mediated transport into the chicken egg yolk. Mol Immunol, 38:619-625.

Nie, R., Wu, D., Hu, G., Zhang, J., Yang, H., Wen, Z., 2004. Effect of specific egg yolk immunoglobulins on phagocytosis by neutrophils. Chin. J. Vet. Med, $12: 23-5$.

Noll, F., Lutsch, G. and Bielka, H., 1982. Structure of $\mathrm{IgG}$ and $\mathrm{IgY}$ molecules in ribosome-antibody complexes as studied by electron microscopy. Immunol Lett, 4: 117-123.

Rose, M.E., Orlans, E. and Buttress, N., 1974. Immunoglobulin classes in the hen's egg: their segregation in yolk and white. Eur. J. Immunol., 4: 521-523.

Schade, R., Staak, C., Hendriksen, C., Erhard, M., Hugl, H., Koch, G., Larsson, A., Pollmann, W., Van Regenmortel, M., Rijke, E. and Spielmann, H., 1996. The production of avian (egg yolk) antibodies: IgY. ATLANOTTINGHAM-, 24: 925-934.

Shimizu, M., Nagashima, H., Sano, K., Hashimoto, K., Ozeki, M., Tsuda, K. and Hatta, H. 1992. Molecular stability of chicken and rabbit immunoglobulin G. Biosci Biotechnol Biochem 56; 270274.

Sui, J., Cao, L. and Lin, H., 2011. Antibacterial activity of egg yolk antibody (IgY) against Listeria monocytogenes and preliminary evaluation of its potential for food preservation. J. Sci. Food. Agric., 91:1946-1950.

Wang, L.H., Li, X.Y., Jin, L.J., You, J.S., Zhou, Y., Li, S.Y. and Xu, Y.P., 2011. Characterization of chicken egg yolk immunoglobulins (IgYs) specific for the most prevalent capsular serotypes of mastitis-causing Staphylococcus aureus. 
Vet. Microbiol., 149:415-421.

Warr, G.W., Magor, K.E. and Higgins, D.A. 1995. IgY clues to the origins of modern antibodies. Immunol. Today, 16, 392-398.

Xu, Y., Li, X., Jin, L., Zhen, Y., Lu, Y., Li, S., You, J. and Wang, L., 2011. Application of chicken egg yolk immunoglobulins in the control of terrestrial and aquatic animal diseases: a review. Biotechnol. Adv., 29:860-868.
Xu, Y., Lin, H., Sui, J. and Cao, L., 2012. Effects of specific egg yolk antibody (IgY) on the quality and shelf life of refrigerated Paralichthys olivaceus. J. Sci. Food Agric., 92:1267-1272.

Zhen, Y.H., Jin, L.J., Guo, J., Li, X.Y., Lu, Y.N., Chen, J. and Xu, Y.P., 2008. Characterization of specific egg yolk immunoglobulin (IgY) against mastitiscausing Escherichia coli. Vet. Microbiol., 130:126-133.

\section{How to cite this article:}

Tapas Paul, Anirban Pal, Sampa Pal and Nilav Aich. 2019. New Dimension in Fish Immunotherapeutics: Avian Egg Yolk Antibody (IgY). Int.J.Curr.Microbiol.App.Sci. 8(07): 86-94. doi: https://doi.org/10.20546/ijcmas.2019.807.012 